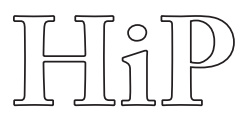

Historia i Polityka

No. $14(21) / 2015$, pp. $25-31$

ISSN 1899-5160

www.hip.umk.pl

DOI: http://dx.doi.org/10.12775/HiP.2015.017

\author{
Natalia LIUTKO \\ Khmelnytsky National University, Ukraine
}

\title{
Positioning as a Part of Political Marketing
}

\begin{abstract}
The political subject is defined as the consumer of goods in the form of political power, political ideas, political leaders, and parties. Political marketing is understood as the identification of political relations and processes with different forms of market exchange and the process of electoral choice as a specific market (the act of purchase and sale). The concept of political positioning appeared as the result of relevant categories of commercial research in the political sphere. Political positioning should be considered as the process of political communication aimed at acquiring by political actor his position in political marketing. It is the most difficult type of political and communication strategic campaigns. This approach allows the candidate (party) to compare his image with electorate's views of desired (acceptable) candidate, political party; compare his image with the image of an opponent; explore the pros and cons of alternative positions; and choose those the most advantageous position for a candidate (party).
\end{abstract}

Keywords: positioning, political framework, political marketing

The theory of marketing as communication theory was firstly engendered in economic literature of the United States in the late $19^{\text {th }}$ century in response to manufacturers and traders selling goods growing problem (crisis of overproduction) and commodity glut. The first works devoted to the application of marketing opportunities for non-commercial areas appeared in the West in the late 1960s. The authors of these works (F. Kotler and L. Slevi) defined the purpose of political marketing as the needs and wishes of sociopolitical and religious organizations participants, state agencies and enterprises. P. Bourdieu made a great contribution in the development of the concept of political "marketing". Having developed different market-based approaches on the basis of theories of "economic and political balance" (V. Pareto) and "competitive democracy" (J. Schumpeter), Bourdieu introduced the concept of "political framework" and created the theory of political marketing. Political marketing is observed as the identification of po- 
litical relations and processes with the forms of market exchange, and the process of electoral choice is defined as a specific market (the act of purchase and sale) ${ }^{1}$. P. Bourdieu transferred political analysis to the player space, where there is not so much the assessment of mathematical patterns as "practical sense" and intuition. Thus, describing the problem of marketing positioning, P. Bourdieu emphasized the importance of political experience that allows the player to accurately navigate the space of existing or potential positions, to capture the disposition of those who have decided to predict the possible and impossible changes of different political positions. According to P. Bourdieu, even the "sense" allows opponents to predict the competitors' acts who play with "no surprises" as it is common in the player space (E. Morozova) $)^{2}$.

The political subject is defined as the consumer of goods in the form of political power, political ideas, political leaders, and parties. The theory of political marketing was developed by public choice theorists (K. Arrow, J. Buchanan, A. Downs, M. Olson, G. Stigler, G. Tullock, and so on) who considered the peculiarities of political marketing through the analysis of the individuals' behavior as rational and egoistic actors.

There are such important characteristic features of political marketing as the interdependence of participants based on the resources exchange and purposes coordination; the absence of monopoly; a certain level of credit among the participants; the existence of clear rules. These rules should be translucentt, conventional, and binding.

Political marketing is interpreted in different ways in political science. Russian researcher E. Morozova considers political marketing as "the system of production and distribution of political goods and services (ideas, programmes, management style, leader's image) which provides a relatively efficient coordination of vendors interests that compete with each other (political parties, politicians, bureaucracy) and consumers (voters, citizens)"3. However, there are a lot of different viewpoints. In particular, modern researcher V. Lapkin characterizes political market as "a grand political auction", G. Diligensky defines electoral marketing as a part of political marketing, that is to supply (dispositions and identities) and demand (attitudes and preferences) as "a kind of lottery tickets

${ }^{1}$ P. Bourdieu, The Political Sociology, Moscow 1993, pp. 336.

2 E. Morozova, Politics in Market and Marketing: Concepts, Models, Techniques, [in:] The Russian Political Encyclopedia, Moscow 1999, p. 247.

${ }^{3}$ Ibidem. 
market" where "the customers" tend to know exactly that the majority of tickets sellers are crooks 4 .

Elections are a distinct element of political marketing in democratic societies. Elections are considered as a meeting place for customers and sellers with the stable rules of the game, but of different forms and functional characteristics of the main participants. "Sellers" and "customers" temporarily reverse roles. The electorate ("sellers") has electoral votes in the market; leaders and parties ("customers") are the recipients of these votes. The first offer their goods under a certain political engagement, such as party program or the leader's charisma, so they become not just the sellers, but they also sell themselves. Leaders and parties also have a dual role; this is because the candidates for high-rank positions are of special value (C. Schmitt). The emergence of such a product as popular votes in the market attracts special interest and competitiveness among consumers (leaders, their supporters or opponents) who form the political class (elite).

In the last decade the new approach of marketing research - strategic product positioning - has formed. Strategic positioning can be borrowed from classical marketing. This approach allows the candidate (party) to compare his image with electorate's views of desired (acceptable) candidate, political party; compare his image with the image of an opponent; explore the pros and cons of alternative positions; and choose those the most advantageous position for a candidate (party). It is worth mentioning that many concepts of the political communication theory, including political positioning, appeared in the result of the development of the relevant categories of commercial research in the political sphere, and the works of such familiar experts in the field of marketing methodology as J. Grunig, T. Hunt, P. Kotler, J. Mauser, G. Stigler, J. Trout, and E. Rice were engaged.

The term "positioning" and its concept was proposed by J. Trout in 1971 in relation to consumer goods. The authors of the concept of positioning J. Trout and E. Rice noticed that "the positioning begins with the goods". This can be a product, service, company, social institution or even a person. But positioning is not that the manufacturer does with his goods. Positioning is an operation on the potential buyers' consciousness. That is, you position the product in the customers' minds.

Therefore, the expression "product positioning" is incorrect. As if you have something to do with the product itself. This is not about the positioning changing. The change of brand name, price or package can not be called the transforma-

${ }^{4}$ G. Diligensky, Political Marketing and Judicious Choice under the Russian Conditions, Polis 2000, no. 2, p. 105. 
tion of the product. In fact, these modifications are aimed at providing favorable position of the product for potential customers. The process of taking one's own "position" in a market segment, in other words, determining the kind of product is called "positioning". Positioning is a tool by using which you will be heard even in our over-communicative society 5 .

Positioning in political marketing and management is broadly defined as a set of approaches aimed at ensuring efficient transactions for such purposes as:

- creating attractive products for the targeted audience;

- improving competitiveness;

- learning and establishing political offers;

- promoting political product;

- making politically-motivated decisions $s^{6}$.

There are certain requirements for the positioning of candidates for attaining a desirable mandate. In this regard, the candidate must have unimprovable political image. And the main thing, the candidate should have proper positioning, according to the structure of the electorate, that is such a determination of all the social groups with the help of which he can win the elections.

F. Ilyasov indicates that different situations can be the base (coordinates) of positioning. Two types of competitive positioning are defined. The first one with the use of a "bad" situation (high crime rate, low living standards, the lack of social justice). In this case, a simple competitive positioning on the principle of tough opposition is carried out. For example: "He (competitor) is bad (covering criminals), and I am good (I will tackle crime up to the end)"; another view point: "He (competitor) is worse, he can not (will not have a reason, determination) to tackle crime effectively. And I can, I am the best".

In the first case, bad situation parameters and methods of propaganda and counter-propaganda are determined according to a special research. These parameters show the candidate's superiority.

The second type of competitive positioning - the parameters of social situations and problems that have ambiguous value for the electorate. It can be global ideological opposition ("capitalism - socialism") or private opposition ("internationalism - nationalism", "extremely liberal economy - strict state regulation","every man for himself - society is responsible for everyone"). The solution for private but controversial (economic) issues ("to build a new high-speed road or not", "to enter

${ }^{5}$ J. Trout, E. Rice, Positioning: The Battle for Your Mind, http://www.books.pchelov.com.

${ }^{6}$ I. Nedyak, Political marketing: Foundations of the theory, Moscow 2008, pp. 98-99. 
the sale and resale of land or do it later", "to build a plant in a given place, house, garage or not") can be taken to this example.

In the second case, the study reveals the following:

a) what kinds of oppositions have a maximum "dividing" ability (that is clearly divide the electorate into supporters and opponents of an idea or a project, and the opposition that affects the largest percentage of potential voters);

b) which opposition has the maximum number of supporters.

An important research task at this stage is to identify the latent opposition and preferences, their usage in advertising campaign can look like a revelation (if nobody knows about it) or if it is implicit (it has an unconscious nature), it may affect subliminal form and require treatment at a subconscious level ${ }^{7}$.

Positioning should be considered as creating a special place (position) of advertised object in accordance with the other objects in the mind of the recipient. As a person can perceive finite amount of information, it is needed to leave some kind of "a place" for advertisement. There are two ways to do it: the first - to unite all the advertising objects of one category into one group and declare that there are no significant differences between them, whereas the new object "X" offers something special. The second - to convince recipients of advertising that with the emergence of the new product other objects of this category will loose their relevance (they will be in one group). A small space should be left in a person's mind to give the most important and useful information ${ }^{8}$.

I. Kudashova defines political positioning as "a method of a particular type of information producing and ensuring its transmission to the appropriate group. So far as a political positioning is concerned, the particular attention should be paid to the political communication, which is the most important mechanism of information space establishment, which produces political judgments, opinions, evaluations"?.

Political positioning is a process of political communication aimed at acquiring by political actor the position in the (global) political system. It is the most difficult type of political and strategic communication campaigns, which has the following parameters: symmetric (based on the principle of feedback information interaction between the communicator and address indicating group); communi-

${ }^{7}$ F. Ilyasov, Political Marketing. Art of Election Winning, Moscow 2000, pp. 200.

${ }^{8}$ M. Medvedev, Branding and Parallel Positioning During the Election Campaign 2003, http:// www.cvk.gov.ua/visnyk/pdf/2013_3/Visnik_3_2013_st_15.pdf/.

9 J. Kudashova, The Problems of Information Environment Establishment of Political Positioning, Public administration 2011, no. 26, http://e-journal.spa.msu.ru/uploads/vestnik/2011/vipusk 26. 
cator's peculiarities (according to his institutional responsibilities); and the status of address indicating groups (the ability to have influence on different policy problems - even foreign policy decisions $)^{10}$.

In political positioning, the formation of objects' images and their symbolism are the key elements. It is arguable that political positioning is the producing method of a particular information type that ensures its transmission to the target groups. However, the report problem of stories, messages with a great influence has become a priority. Thereby, this task depends on several factors. The media scene is a law unto itself, it is formed by the multidirectional flow of information and ensures the reproduction of different discourse types.

Positioning as directed activity should be built as an independent information and communication system that has its own structure, stable broadcast information channel and specific semantic content that reveal the required angle of the concerned object.

In the political space positioning involves attributing objects with such political values that are able to provide not only the recognition, but also to show their specificity, qualitative differences, thus providing a more favorable position in the system of political proportion.

It is widely acknowledged to observe two models of political positioning: the spatial model and the prominence model. The prominence model connects the message with a specific topic which dominates the business of the day ${ }^{11}$.

The spatial model is very interesting in the sense of political positioning. It assumes that political parties compete with each other in a space which poles are any values or ideological orientations.

Taking into consideration all the above and relying on marketing methodology, strategy development campaign can be defined as the stage at which four problems: political market study, its segmentation, positioning, and political production are solved, while the tactics core task is the political marketing promotion. Furthermore, the main problems for the election campaign management, its organizational and resources establishment are solved at the level of strategy.

As is evident from the foregoing, one of the key tasks in this context is the positioning that takes a special place in the organization practice and conducting

${ }^{10}$ R. Golovanov, Political Positioning of the New Integrating Association on the Post-Soviet Region, http://dissercat.com/content/politicheskoe-pozitsionirovanie-novykh-integratsionnykh-obedinenii-na-postsovetskom-prostran\#ixzz3H4JLfWjq.

${ }^{11}$ D. Farrell, R. Kolodny, S. Medvic, Parties and Campaign Professionals in a Digital Age: Political Consultants in the United States and Their Counterparts Overseas, Harvard International Journal of Press 2001, no. 4, pp. 11-30. 
election campaigns. First of all, the effectiveness of election strategy depends on it, while an incorrectly selected positioning option can bring to nothing all the further efforts.

A lot of specialists in election technology with great experience in the postSoviet region usually emphasize the need for an integrated positioning approach that would ensure the consideration of all the important electoral divisions that exist between voters in different states. 